Journal of Contemporary Educational Research

Research Article

\title{
Contributors to the Decline of English Specialty in China and Coping Strategies
}

Fuhua Liu

School of Foreign Languages, Dalian Jiaotong University, Dalian 116028, Liaoning Province, China

\begin{abstract}
The present paper is a detailed analysis of the decline of English specialty in China. Based on the three contributors analyzed, the paper continues to offer corresponding coping strategies to resolve the challenges facing English specialty.

Key words: English specialty; Decline; Contributors; Coping strategies

Publication date: September, 2020

Publication online: 30 September, 2020

*Corresponding author: Fuhua Liu, taolichengxi@126. com
\end{abstract}

\section{Introduction}

Professor Cai Jigang once claimed that "Most of the students majoring in English graduate merely as qualified language users, but by no means masters of the language ${ }^{[1]}$." Compared with other majors, English majors are said to have had the toughest time finding jobs upon graduation in the past few years. The decline of English specialty has formed a vivid contrast with its glorious past. Actually, the dilemma for English specialty today has sparked a nationwide discussion as to what contributes to the decline of this very specialty and what the possible way out is.

\section{Body}

\subsection{Contributors to the Decline of English Specialty}

The overall situation in foreign language universities, normal universities and universities of humanities is relatively less worrisome. However, universities of science show a noticeable decline in English specialty. First of all, a market-oriented student enrolling strategy possibly accounts for the decline of English specialty as well as its prosperity. In the 1980s and 1990s, to some degree, English specialty ensures a student's career prospect, as an incredible number of enterprises especially foreign ones require English proficiency. Private-owned training schools also mushroomed at that time. To meet this social demand, English departments in almost all universities across China began to enroll senior high school graduates on an unprecedented scale. However, with the popularization of the learning of English language and the advancement of computer technology, the social demand for pure English talents inevitably decline.

The second challenge stems from the fast growing and thriving of college English for non-English majors. A large number of non-English majors have acquired CET 4 or even CET 6 certificates. Some of them are not at all inferior to English majors in terms of language proficiency, especially when taken into consideration the complex situation in China. For example, a non-English major from a key national-level university is more likely to be a better English language learner and user than an English major from a provincial-level university. Besides, with the development of high technology, nonEnglish majors have easier access than before to all kinds of authentic English materials. Therefore, as long as a student shows his or her eagerness, commitment and self-discipline in the second language acquisition process, he or she will be well on his or her way to the mastery of the language. In a word, the gap between English and non-English majors has been narrowed to the minimum.

Third, in Zha Mingjian's view, English specialty is 
not supposed to be a combination of its instrumentality and humanity, let alone its mere instrumentality. For him, like the Chinese specialty, English specialty is a specialty belonging to the humanity ${ }^{[2]}$. There is all the truth in what Zha has said, but this idealized account will only make English specialty shrink and wither. This humanity-oriented philosophy will make English specialty further lose its charm and competitiveness in a career-oriented market trend and a further popularized higher education. That is why the Ministry of Education in as early as 1998 defines English as a means instead of a specialty.

\subsection{Coping Strategies}

To cope with the challenges facing English specialty, we must first of all make clear the three contrasting pairs mentioned above. They are market-oriented and non-market-oriented educational principles, English specialty for English majors and college English for non-English majors and instrumentality and humanity. English specialty is stimulated into existence by market-oriented school-running philosophy, but such philosophy also contributes to its decline as it fails to keep pace with a changed reality. To further implement the market-oriented educational philosophy in a new era, English departments of most universities should offer major courses such as business, law, tourism and so on in English language. A combination of English language means and practical major content is necessary for English majors' future career establishment and development.

One point I would like to highlight here is that despite a market-oriented educational philosophy, we should by no means ignore or underestimate the non-marketoriented philosophy which refers to the comprehensive cultivation of students' academic capabilities, morality and mentality. Higher education for any specialty is in essence general education. And this is especially true for a humanity specialty like English specialty. The incorporation of humanity which may also be achieved in basic courses for English majors does not necessarily mean the detailed study of English or American literature. And even the exploration of literature cannot guarantee a sound and healthy soul of students. In the real teaching practice, teachers should purposefully pick up some humanistic materials and extend a bit to cultivate students' mind. Therefore, while students of English specialty elaborate on a certain practical major, they are also given a chance to constantly enhance their morality while learning general English.
Second, we should support the bankruptcy of English specialty for some universities, especially non-key universities of science. Zha claims in his paper, "To our delight, having realized their deficiency in running the program, some universities are sensible enough to voluntarily shut down their English specialty and transfer their teachers of English specialty to college English which covers a much larger number of students. That makes a practical choice and will benefit English specialty in the long run ${ }^{[2]}$." Indeed, higher education should never be totally commercialized. It does require humanity. On the one hand, to follow the market trend, we should substitute college English courses for English specialty of non-key universities of science over time. The focus of humanity enhancement in English specialty may be equally achieved in college English courses, which is especially true when taken into account the ongoing practice of moral integration into college English courses. For example, the essence of English specialty such as the appreciation of English literary classics may be integrated into college English courses in the initial stage or be established as an independent course in the senior stage. On the other hand, to achieve the goal of cultivating "masters" put forward by Zha, we should definitely retain the English specialty for some first-level universities and foreign language universities in which students can further study linguistics, English and American literature, translation etc.

Third, if we tend to define English specialty as a humanity, we should start by emphasizing relevant teachers' and students' instrumentality. That is, a teacher or student's language abilities lay the very foundation for teaching or receiving humanistic ideas. An English teacher with a weak language foundation will definitely fail to comprehend complex humanistic materials, let alone teaching them in English. The same is true of students. To a large extent, we can conclude that the definition of English specialty as a humanity requires English proficiency and width and depth of the study of humanistic knowledge both for teachers and students. The definition is fit for targeting elite students in some first-tier 985 universities or specialized foreign language universities in which some students have true interests and gifts for such further study in literature, linguistics, translation and many other fields. These elite students who probably stick to their study until they get the doctor's degree have a greater chance of becoming "masters" put forward by professor Zha. 
What is more important in the new age is that we should also cultivate students who are interested in Chinese culture and literature or comparative literature between Chinese literature and western literature in a bid to transmit Chinese culture and literature overseas. We do not deny some of the merits in English and American culture and literature, but meanwhile we should be confident about our own native culture and literature and develop a stronger urge to explore them. One thing to point out is that there is a real difference between the study of Chinese culture and literature in English and that of Chinese culture and literature in our native tongue. The former intends to carry out the study from a worldwide perspective and thus has acquired a practical purpose of influencing foreigners' world views and values through cross-cultural communication and comparative studies.

\section{Conclusion}

To find the contributors to the decline of English specialty and the possible solutions to its current dilemma, the paper lists the specific challenges facing English specialty, analyzes the causes and offers feasible solutions. A market-oriented student enrolling strategy, the fast growing and thriving of college
English for non-English majors and the idealized position of English specialty as a humanity specialty by many universities all contribute to the decline of English specialty. To cope with the challenges facing English specialty, we must distinguish three contrasting pairs: market-oriented and non-market-oriented educational principles; English specialty for English majors and college English for non-English majors and instrumentality and humanity. We should shut down English specialty of non-key universities of science over time and retain the further studies of English specialty (English and American literature, linguistics, translation etc.) and add Chinese culture and literaturerelated studies in English language in key nationallevel universities and specialized foreign language universities in which students have solid language foundations and keen interests.

\section{References}

[1] Cai JG. Crisis of English Specialty and the Way Out from the Perspective of National Economic Development Needs[J]. Contemporary Foreign Languages Studies, 2018(6).

[2] Zha MJ. The Dilemma Facing English Specialty and the Way Out [J]. Contemporary Foreign Languages Studies, 2018(6). 